\title{
Role of Cytochrome P450 Monooxygenase in the Bioactivation of Aflatoxin B1
}

(Peranan Sitokrom P450 Monooksigenase dalam Biopengaktifan Aflatoksin B1)

SUREEPORN NUALKAEW, HIRUN SAELIM,

DANAi TIWAWECh, TANATE PANRAT IMRAN PARVEZ \& AMORNRAT PHONGDARA*

\begin{abstract}
In a previous study, the gene EgP450 that encodes the proteins of 505 amino acids was isolated from oil palm. The recombinant protein EgP450 is bound to phenylurea-like herbicides which detoxify the substance. Aflatoxin $B 1$ ( $\left.A F B_{1}\right)$, a mycotoxin produced by Aspergillus sp., is another toxic compound that is known to cause acute toxic effects and act as a hepatocarcinogenic agent. This study aimed to examine the role of EgP450 enzyme in mycotoxin bioactivation in human mesenchymal stem cells (hMSCs). Docking analysis showed that $\mathrm{Eg} P 450$ is bound to the group of carcinogens, which includes $A F B_{l}, n$-(2-fluorenyl) acetamide, n-n-butyl-n-butan-4-ol-nitrosamine, n-nitrosodiethylamine, $n$-nitrosodiethylamine and n-nitrosodimethylamine. An in vivo aflatoxin toxicity test on $h M S C s$ and AFB induces the expression of Bmi-1 which is one of the markers for the development of cancer. The presence of $\operatorname{Eg} P 450$ at $0.15 \mu \mathrm{g} / \mathrm{mL}$ could reduced the Bmi-1 expression in AFB induced cells. Moreover, this protein also showed some antioxidant activity. These results exhibited the enormous potential of $\mathrm{Eg} P 450$ in the detoxification processes.
\end{abstract}

Keywords: Carcinogen; cytochrome P450 monooxygenase; detoxification

ABSTRAK

Dalam kajian sebelum ini, gen EgP450 yang mengekod 505 protein asid amino telah dipencilkan daripada kelapa sawit. Protein rekombinan EgP450 terikat kepada racun herba seperti phenylurea yang menyahtoksin bahan. Aflatoksin B1 $\left(A F B_{1}\right)$, mikotoksin yang dihasilkan oleh Aspergillus sp., adalah satu lagi toksik sebatian yang diketahui menyebabkan kesan toksik akut dan bertindak sebagai agen hepatokarsinogen. Kajian ini bertujuan untuk meneliti peranan enzim EgP450 dalam biopengaktifan mikotoksin sel stem mesenkim manusia (hMSCs). Analisis dok menunjukkan bahawa EgP450 terikat kepada kumpulan karsinogen, termasuk AFB, n-(2-fluorenil) asetamid, n-n-butil-n-butan-4-olnitrosamin, n-nitrosodietilamin, n-nitrosodietilamin dan n-nitrosodimetilamin. Ujian in vivo ketoksikan aflatoksin ke atas hMSCs dan AFB ${ }_{1}$ mengaruh ekspresi Bmi-1 yang merupakan salah satu penanda bagi pembangunan kanser. Kehadiran EgP450 pada $0.15 \mu \mathrm{g} / \mathrm{mL}$ boleh mengurangkan ekspresi Bmi-1 dalam sel aruhan AFB. Selain itu, protein ini juga menunjukkan beberapa aktiviti antioksidan. Keputusan ini menunjukkan potensi besar EgP450 dalam proses penyahtoksikan.

Kata kunci: Karsinogen; penyahtoksikan; sitokrom P450 monooksigenase

\section{INTRODUCTION}

Aflatoxins form a major group of mycotoxin. They occur in a wide range of human foodstuffs and can cause hepatocarcinogenesis in animals (Groopman et al. 1988; Portman et al. 1970; Vesselinovitch et al. 1972; Wogan 1973). In addition, epidemiological studies showed that humans are possibly susceptible to aflatoxin induced hepatocarcinogenesis (Bulatao-Jayme et al. 1982; Groopman et al. 1988; Peers \& Linsell 1973; Peers et al. 1987). Aflatoxin $B 1\left(\mathrm{AFB}_{1}\right)$ is thought to be the most carcinogenic aflatoxin. It requires the oxidation of the 8 , 9 double bond of $\mathrm{AFB}_{1}$ in order to yield the biologically active $\mathrm{AFB}_{1}-8,9$-epoxide. $\mathrm{AFB}_{1}-8,9$-epoxide in turn can react with DNA, whereas, microsomal cytochrome P450 (CYP)-mediated $\mathrm{AFB}_{1}$ oxidation produces various hydroxylated metabolites such as aflatoxin $\mathrm{Ml}\left(\mathrm{AFM}_{1}\right)$, aflatoxin $\mathrm{Pl}\left(\mathrm{AFP}_{1}\right)$ and aflatoxin $\mathrm{Q} 1,\left(\mathrm{AFQ}_{1}\right)$. These are much less toxic than the original aflatoxins. In human liver microsomes, $\mathrm{AFM}_{1}$ and $\mathrm{AFQ}_{1}$ are the main oxidative detoxification products of $\mathrm{AFB}_{1}$ (Ramsdell et al. 1991; Raney et al. 1992).

$\mathrm{P} 450$ s are widespread in nature, i.e. they can be found in all organisms. P450 enzymes that metabolize xenobiotics play a key role in the oxidative metabolism of a wide range of exogenous as well as endogenous compounds including plant toxins, environmental carcinogens and a wide variety of anticancer drugs. P450 enzymes in human liver are, in the first place, responsible for the activation of $\mathrm{AFB}_{1}$ to $\mathrm{AFB}_{1}-8,9$-epoxide which is electrophilic. Several studies reported that there are five distinct human liver P450s, including 1A2, 2A6, 2B7, $3 \mathrm{~A} 3,3 \mathrm{~A} 4$ and $2 \mathrm{~A} 13$ that can activate $\mathrm{AFB}_{1}$ to mutagenic 
metabolites and derivatives bound to DNA (Aoyama et al. 1990; He et al. 2006; Kensler et al. 2011). In the human liver, microsomes CYP3A4 is the most important P450 enzyme involved in the activation of $\mathrm{AFB}_{1}$ to genotoxic $\mathrm{AFB}_{1}-8,9$-epoxide or to the nontoxic $3 \alpha$-hydroxy $\mathrm{AFB}_{1}$ (Shimada et al. 1989). It has been suggested that human CYP1A2 is the P450 with high affinity that is responsible for the bioactivation of $\mathrm{AFB}_{1}$ at low concentrations which is comparable to high concentrations in the human diet (Crespi et al. 1991). Additional data are also congruent with the hypothesis that in human liver microsomes, CYP1A2 is the main P450 involved in the oxidation of $\mathrm{AFB}_{1}$ to $\mathrm{AFM}_{1}$, whereas, CYP3A4 is the predominant $\mathrm{P} 450$ responsible for the conversion of $\mathrm{AFB}_{1}$ to $\mathrm{AFQ}_{1}($ Gallagher et al. 1996, 1994; Guengerich et al. 1998).

Previously, EgP450 was demonstrated as the most efficient oil palm CYPenzyme that can protect rice seedlings from exogenous herbicides of the phenylurea family. The present study aimed to characterize the role of $\mathrm{EgP} 450$ enzyme in $\mathrm{AFB}_{1}$ bioactivation in human stem cells which leads to the activation or detoxification of $\mathrm{AFB}_{1}$.

\section{MATERIALS AND METHODS}

\section{MOLECULAR DOCKING SIMULATIONS AND INTERACTION ANALYSIS}

The molecular interactions docking was used for screening the $E g \mathrm{P} 450$ with various chemicals and carcinogens using the AutoDOCK simulation tool, whereas, the EgP450 is the receptor protein and set of the substrates are ligand molecules (Huey et al. 2007; Morris et al. 1996) and the SLITHER server (Lee et al. 2009).

\section{PREPARATION AND PURIFICATION OF RECOMBINANT EGP450}

The recombinant protein was prepared from Escherichia coli BL21 (DE3) harbouring EgP450 according to the method previously described (Phongdara et al. 2012).

\section{CULTURE OF HMSCS AND AFB TREATMENT $_{1}$}

hMSCs were cultured on medium containing mesenchymal stem cell growth medium (Biomed Diacnostic, Thailand) supplemented with supplement mix mesenchymal stem cell growth medium. Then $1 \%$ of penicillin/streptomycin (Biochrom, Berlin, Germany) was put into the culture which was continued in the first culture for $48 \mathrm{~h}$. The culture was maintained at $5 \% \mathrm{CO}_{2}$ under the humidifier at $37^{\circ} \mathrm{C}$. To determine a cytotoxic concentration of $\mathrm{AFB}_{1}$ the stem cells were treated with chemical at concentrations of $\mathrm{AFB}_{1} 0 \mathrm{mg} / \mathrm{mL}$ and $0.0625 \mathrm{mg} / \mathrm{mL}$ for $24 \mathrm{~h}$. In order to evaluate $\mathrm{P} 450$ effects $(0.15,0.30$ and $0.60 \mu \mathrm{g} / \mathrm{mL}$, respectively), after plating the toxin, the culture medium was mixed at the appropriate concentrations. After 24 $\mathrm{h}$, culture sera was collected after the toxin treatment. Cytotoxicity was evaluated by real-time quantitative polymerase chain reaction.

\section{BMI-1 MRNA EXPRESSION IN STEM CELLS}

B-cell-specific moloney murine leukemia virus integration site 1 (Bmi-1), is a prognostic marker in many cancers (Mihara et al. 2006; Song et al. 2006). Bmi-1 expression levels were quantified in cultured cells of the hMSCs by realtime quantitative polymerase chain reaction. The mRNA levels were standardized using glyceraldehyde 3-phosphate dehydrogenase (GAPDH) as a reference housekeeping gene. The data were analyzed using $2^{-\triangle \triangle \mathrm{CT}}$ method normalized with GAPDH (Livak \& Schmittgen 2001).

\section{MEASURING OF ANTIOXIDANT ACTIVITY OF EgP450 BY CHEMILUMINESCENCE : XANTHINE - XANTHINE OXIDASE SYSTEM}

The xanthine oxidase inhibition assay was measured spectrophotometrically by using the procedure of Vieira et al. (2009). Antioxidant activity assay was calculated using the formula:

Antioxidant activity

$=1-[(\operatorname{Sample}(\mathrm{P})-\operatorname{Sample}(\mathrm{N})) /($ Positive control $)$ - (Negative control)].

\section{RESULTS AND DISCUSSION}

\section{MOLECULAR DOCKING SIMULATIONS AND INTERACTION ANALYSIS}

The docking results clearly show that $E g \mathrm{P} 450$ binds to carcinogens such as $\mathrm{AFB}_{1}, \mathrm{n}$-(2-fluorenyl) acetamide (2-AAF), n-n-butyl-n-butan-4-ol-nitrosamine (BBN) n-nitrosodiethylamine (DEN) and n-nitrosodimethylamine (DMN) (Figure 1). The lowest docking score of EgP450/ $\mathrm{AFB}_{1}$ interaction model gave the best docking energy of $-9.7 \mathrm{Kcal} / \mathrm{mol}$ (Table 1$)$.

\section{EXPRESSION AND PURIFICATION OF EgP450}

The analysis of $E g \mathrm{P} 450$ enzyme of BL21 (DE3) cells on SDSPAGE obviously showed the target size of the recombinant protein fused to the histidine-tag and a 55-kDa molecular mass (Figure 2). The bacterial cells were lysed in a lysis buffer and purified by using affinity column. Most of the soluble recombinant $\mathrm{P} 450$ was bound to the column and eluted in the flow through in its denatured form and subsequently allowed to refold during cut-off column.

\section{EFFECTS OF RECOMBINANT EGP450 PROTEIN ON STEM CELL IN VIVO}

In order to see the effect of $\mathrm{AFB}_{1}$ on the stem cell hMSCs, cells were cultivated and treated with various concentrations to $\mathrm{AFB}_{1}$. Finally, the concentration of 0.0625 was chosen in this study. Several treatments which included $E g \mathrm{P} 450$ were designed to demonstrate the counter effect of the protein. $\mathrm{Bmi}-\mathrm{l}$ is a prognostic marker in many cancer development. The Bmi-1 expression interacts with several signaling containing Wnt, Akt, Notch, Hedgehog and receptor tyrosine kinase (RTK) pathway. Here, we develop a method 


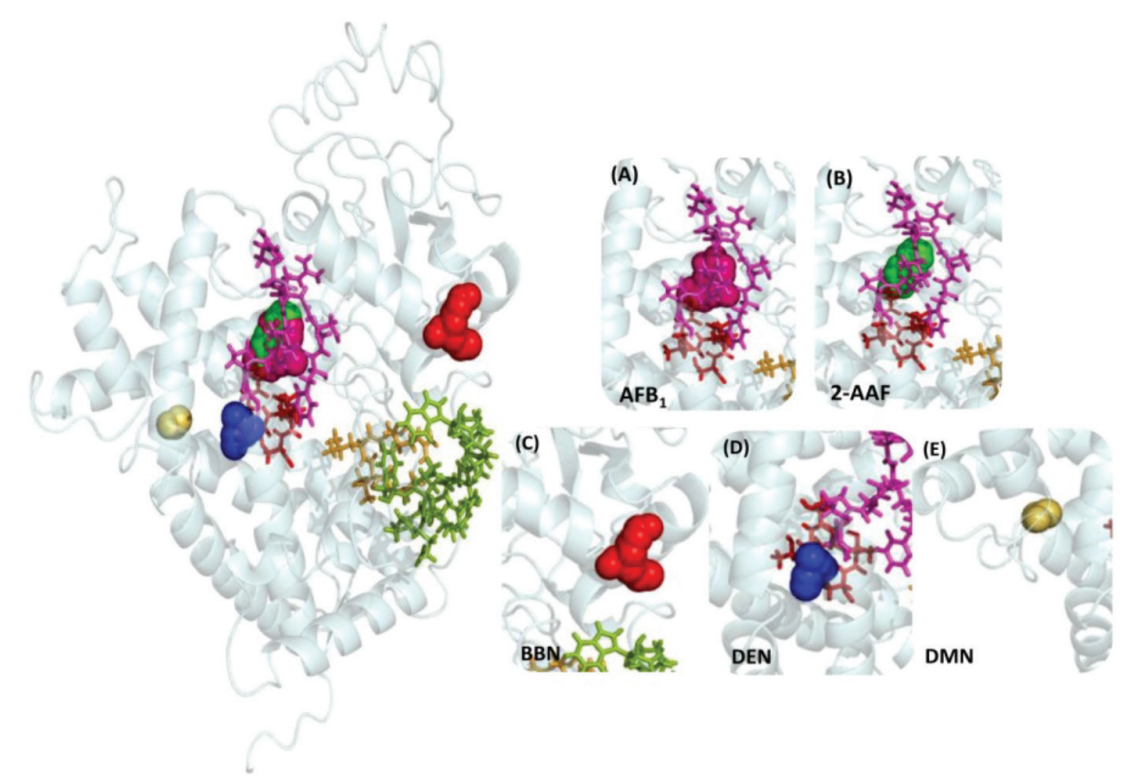

FIGURE 1. Molecular interaction models of $E g \mathrm{P} 450$ and carcinogens. The binding of $E g \mathrm{P} 450$ to the $\mathrm{AFB}_{1}(\mathrm{~A})$, n-(2-fluorenyl) acetamide (B), n-n-butyl-n-butan-4-ol-nitrosamine (C), n-nitrosodiethylamine (D) and n-nitrosodimethylamine (E)

TABLE 1. Energy table of $E g \mathrm{P} 450$ and carcinogens interaction simulations

\begin{tabular}{lc}
\hline Chemical Name & Affinity $(\mathrm{Kcal} / \mathrm{Mol})$ \\
\hline Aflatoxin B1 $\left(\mathrm{AFB}_{1}\right)$ & $-8.9--9.7$ \\
$N$-(2-fluorenyl) acetamide (2-AAF) & $-7.9--8.0$ \\
$N$ - $N$-butyl-N-butan-4-ol-nitrosamine (BBN) & $-4.5--5.1$ \\
$N$-nitrosodiethylamine (DEN) & $-4.0--4.0$ \\
$N$-nitrosodimethylamine (DMN) & $-3.3--3.5$ \\
\hline
\end{tabular}

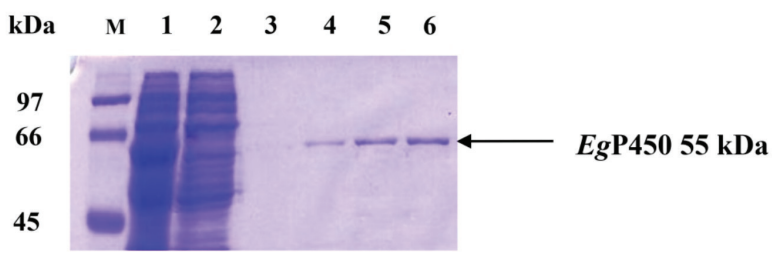

*The arrow indicates the recombinant protein

FIGURE 2. Purification of $E g \mathrm{P} 450$ as visualized on SDS-PAGE. The overexpressed protein is visible at $55 \mathrm{kDa}$ after induction with IPTG. Lane 1: cell extracts, lane 2: lysis cell, lane 3:

fraction after washing, lane 4-6: enzyme purification, lane M: standard of molecular weight

to screen a potential toxic and detoxification substances by measuring the expression level of Bmi-1.

Figure 3 demonstrates the increase of $B m i-1$ expression in hMSCs treated with $\mathrm{AFB}_{1}$ when compared with the control (without $\mathrm{AFB}_{1}$ ), whereas, the expression of $B m i-1$ is low or near normal when included at low concentration of $E g \mathrm{P} 450$ together with $\mathrm{AFB}_{1}$. However, at the high concentration of $E g P 450(0.30$ and $0.60 \mu \mathrm{g} / \mathrm{mL})$, EgP450 helped $\mathrm{AFB}_{1}$ to enhance the Bmi-1 expression.
These data suggest that the $E g \mathrm{P} 450$ protein is involved in both the metabolic activation and the detoxification of $\mathrm{AFB}_{1}$. Therefore, it is recommended to use the appropriate low concentration of $E g \mathrm{P} 450$ in the treatment.

\section{P450 ENZYME ANTIOXIDANT ACTIVITY}

The ability of the enzyme was evaluated by Xanthine/2methyl-6-p-methoxyphenylethynyl-imidazopyrazinone (MPEC)/xanthine oxidase (XOD) assay. The inhibition of luminescent emission caused by the decrease of superoxide anions was measured using a luminometer. Counting of photons per minute and inhibition percentage of luminescence of the samples are shown in Table 2.

The inhibition percentage of $E g \mathrm{P} 450$ at high concentration $(50 \mu \mathrm{g} / \mathrm{mL})$ was superior when compared to lower concentration (20 and $35 \mu \mathrm{g} / \mathrm{mL}$ ). However, the activity is not high when compared to the control Vitamin C.

\section{CONCLUSION}

A molecular docking analysis showed that $E g \mathrm{P} 450$ specifically binds to carcinogens, $\mathrm{AFB}_{1}$, n-(2- 

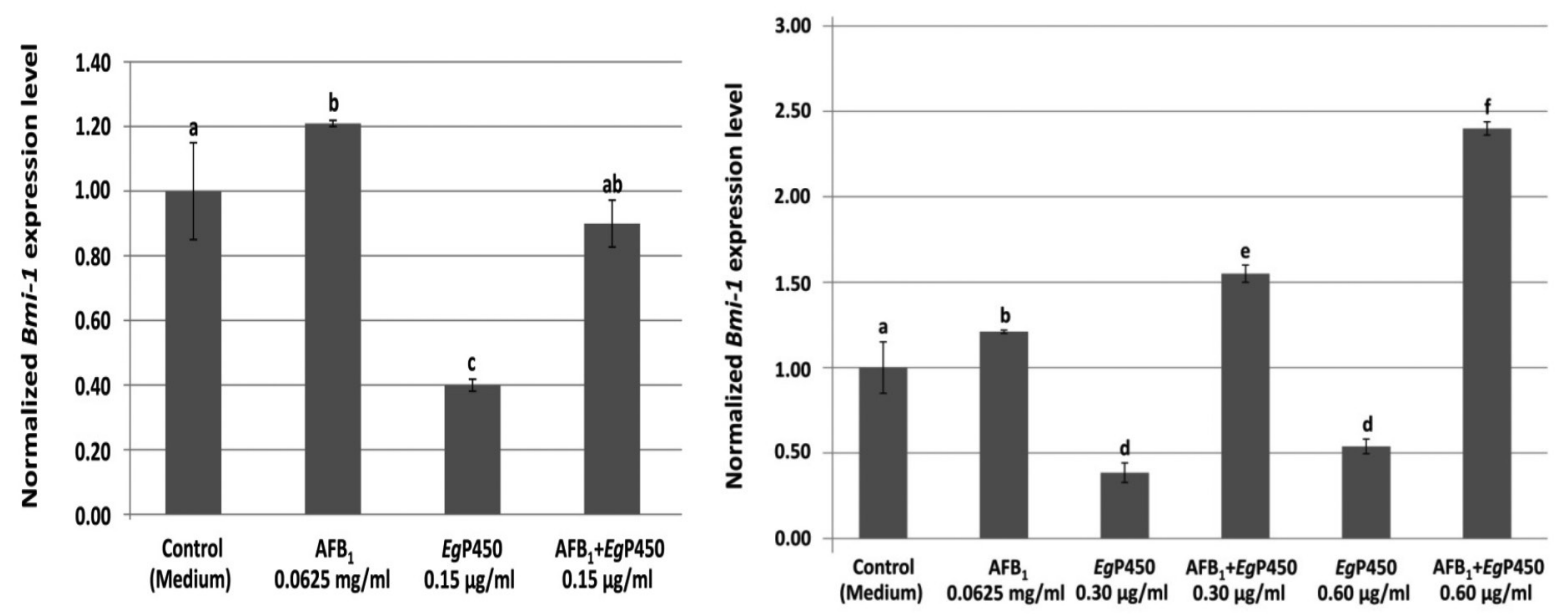

FIGURE 3. Expression of Bmi-1 mRNA in stem cell hMSC treated with $\mathrm{AFB}_{1} 0.0625 \mathrm{mg} / \mathrm{mL}$ and the $E g \mathrm{P} 4500.15,0.30$ and $0.60 \mu \mathrm{g} / \mathrm{mL}$ by real-time PCR

TABLE 2. Photon count per minute and inhibition percentage of luminescence of enzyme

\begin{tabular}{lccc}
\hline \multirow{2}{*}{ Measurement } & \multicolumn{2}{c}{ Chemiluminescence emission } & \multirow{2}{*}{$\%$ Inhibition } \\
\cline { 2 - 3 } & Dilution buffer $(\mathrm{N})$ & Enzyme solution $(\mathrm{P})$ & \\
\hline Negative control & 7,058 & $77,913,538$ & - \\
Vitamin C & 6,839 & 23,064 & 99.97 \\
$E g \mathrm{P} 45020 \mu \mathrm{g} / \mathrm{mL}$ & 7,831 & $81,548,763$ & 0.000 \\
$E g \mathrm{P} 45035 \mu \mathrm{g} / \mathrm{mL}$ & 6,682 & $72,509,647$ & 6.936 \\
EgP450 $48 \mu \mathrm{g} / \mathrm{mL}$ & 23,992 & $66,995,692$ & 14.013 \\
\hline
\end{tabular}

fluorenyl) acetamide (2-AAF), n-n-butyl-n-butane-4ol-nitrosamine (BBN) n-nitrosodiethylamine (DEN) and n-nitrosodimethylamine (DMN). This is the first time a stem cell hMSCs was used to study the genotoxic of $\mathrm{AFB}_{1}$ and its potential inhibitory effector, $E g \mathrm{P} 450$. The study provides a screening method and showed that low concentration of $E g \mathrm{P} 450$ possesses metabolic activity against the carciogenic effect of $\mathrm{AFB}_{1}$.

\section{ACKNOWLEDGEMENTS}

This work was supported by the government budget of Prince of Songkla University (SCI580447S), the Royal Golden Jubilee Ph.D. Program (Grant No. PHD/0253/2553) to Hirun Saelim, the Center for Genomics and Bioinformatics Research, the Faculty of Science, and Prince of Songkla University.

\section{REFERENCES}

Aoyama, T., Yamano, S., Guzelian, E.S., Gelhoin, H.V. \& Gonzales, E.J. 1990. Five of 12 forms of vaccinia virusexpressed human hepatic cytochrome P450 metabolically activate aflatoxin B1. Proceedings of the National Academy of Sciences 87: 4790-4793.

Bulatao-Jayme, J.,Almero, E.M., Castro, M.C., Jardeleza, M.T. \& Salamat, L.A. 1982. A case-control dietary study of primary liver cancer risk from aflatoxin exposure. International Journal of Epidemiology 11(2): 112-119.
Crespi, C.L., Penman, B.W., Steimel, D.T., Gelboin, H.V. \& Gonzalez, E.J. 1991. The development of a human cell line stably expressing human CYP3A4: Role in the metabolic activation of aflatoxin $\mathrm{B} 1$ and comparison to CYP1A2 and CYP2A3. Carcinogenesis 12(2): 255-259.

Gallagher, E.P., Kunze, K.L., Stapleton, P.L. \& Eaton, D.L. 1996. The kinetics of aflatoxin B1 oxidation by human cDNA-expressed and human liver microsomal cytochromes P450 1A2 and 3A4. Toxicology and Applied Pharmacology 141(2): 595-606.

Gallagher, E.P., Wienkers, L.C., Stapleton, P.L., Kunze, K.L. \& Eaton, D.L. 1994. Role of human microsomal and human complementary DNA-expressed cytochromes P4501A2 and P4503A4 in the bioactivation of aflatoxin B1. Cancer Research 54(1): 101-108.

Groopman, D., Cain,L.G. \& Kensler, T. 1988. Aflatoxin exposure in human populations: Measurements and relationship to cancer. Critical Reviews in Toxicology 19(2): 113-143.

Guengerich, F.P., Johnson, W.W., Shimada, T., Ueng, Y.F., Yamazaki, H. \& Langouët, S. 1998. Activation and detoxication of aflatoxin B1. Mutation Research 402(1\&2): 121-128.

He, X.Y., Tang, L., Wang, S.L., Cai, Q.S., Wang, J.S. \& Hong, J.Y. 2006. Efficient activation of aflatoxin B1 by cytochrome P450 2A13, an enzyme predominantly expressed in human respiratory tract. International Journal of Cancer 118(11): 2665-2671.

Huey, R., Morris, G.M., Olson, A.J. \& Goodsell, D.S. 2007. A semiempirical free energy force field with charge-based desolvation. Journal of Computational Chemistry 28(6): $1145-1152$ 
Kensler, T.W., Roebuck, B.D., Wogan, G.N. \& Groopman, J.D. 2011. Aflatoxin: A 50-year odyssey of mechanistic and translational toxicology. Toxicological Sciences 120(S1): S28-S48.

Lee, P.H., Kuo, K.L., Chu, P.Y., Liu, E.M. \& Lin, J.H. 2009. SLITHER: A web server for generating contiguous conformations of substrate molecules entering into deep active sites of proteins or migrating through channels in membrane transporters. Nucleic Acids Research 37: W559-W564.

Livak, K.J. \& Schmittgen, T.D. 2001. Analysis of relative gene expression data using real- time quantitative PCR and the 2- $\Delta \Delta \mathrm{CT}$. Methods 25(4): 402-408.

Mihara, K., Chowdhury, M., Nakaju, N., Hidani, S., Ihara, A., Hyodo, H., Yasunaga, S., Takihara, Y. \& Kimura, A. 2006. Bmi-1 is useful as a novel molecular marker for predicting progression of myelodysplastic syndrome and prognosis of the patients. Blood 107(1): 305-308.

Morris, G.M., Goodsell, D.S., Huey, R. \& Olson, A.J. 1996. Distributed automated docking of flexible ligands - to proteins: Parallel applications of AutoDock 2.4. Journal of Computer-Aided Molecular Design 10(4): 293-304.

Peers, E., Bosch, X., Kaldor, J., Linsell, A. \& Pluumen, M. 1987. Aflatoxin exposure, hepatitis B virus infection and liver cancer in Swaziland. International Journal of Cancer 39(5): 545-553.

Peers, E. \& Linsell, C.A. 1973. Dietary aflatoxins and liver cancer-a population based study in Kenya. British Journal of Cancer 27(6): 473-483.

Phongdara, A., Nakkaew, A. \& Nualkaew, S. 2012. Isolation of the detoxification enzyme EgP450 from an oil palm EST library. Pharmaceutical Biology 50(1): 120-127.

Portman, R.S., Plowman, K.M. \& Campbell, T.C. 1970. On mechanisms affecting species susceptibility to aflatoxin. Biochimica et Biophysica Acta 208(3): 487-495.

Ramsdell, H.S., Parkinson, A., Eddy, A.C. \& Eaton, D.L. 1991. Bioactivation of aflatoxin B1 by human liver microsomes: Role of cytochrome P450 IIIA enzymes. Toxicology and Applied Pharmacology 108(3): 436-447.

Raney, K.D., Shimada, T., Kim, D-H., Groopman, J.D., Harris, T.M. \& Guengerich, F.P. 1992. Oxidation of aflatoxins and sterigmatocystin by human liver microsomes: Significance of aflatoxin-Q1 as a detoxication product of aflatoxin-B1. Chemical Research in Toxicology 5(2): 202-210.
Shimada, T. \& Guengedch, E.E. 1989. Evidence for cytochrome $\mathrm{P}-450 \mathrm{NF}$, the nifedipine oxidase, being the principal enzyme involved in the bioactivation of aflatoxins in human liver. Proceedings of the National Academy of Sciences 86(2): 462-465.

Song, L.B., Zeng, M.S., Liao, W.T., Zhang, L., Mo, H.Y., Liu, W.L., Shao, J.Y., Wu, Q.L., Li, M.Z., Xia, Y.F., Fu, L.W., Huang, W.L., Dimri, G.P., Band, V.\& Zeng, Y.X. 2006. Bmi1 is a novel molecular marker of nasopharyngeal carcinoma progression and immortalizes primary human nasopharyngeal epithelial cells. Cancer Research 66(12): 6225-6232.

Vesselinovitch, S.D., Mihailovich, N., Wogan, G.N., Lombard, L.S. \& Rao, K.V.N. 1972. Aflatoxin B1, a hepatocarcinogen in the infant mouse. Cancer Research 32: 2289-2291.

Vieira, P.M., Francisco, A.F., Souza, S.M., Malaquias, L.C., Reis, A.B., Giunchetti, R.C., Veloso, V.M., de Lana, M., Tafuri, W.L. \& Carneiro, C.M. 2009. Trypanosoma cruzi: Serum levels of nitric oxide and expression of inducible nitric oxide synthase in myocardium and spleen of dogs in the acute stage of infection with metacyclic or blood trypomastigotes. Experimental Parasitology 121(1): 76-82.

Wogan, G.N. 1973. Host environment interactions in the etiology of cancer in man. Cancer Research 7: 237-241.

Center for Genomics and Bioinformatics Research Department of Molecular Biotechnology and Bioinformatics Faculty of Science, Prince of Songkla University

Hatyai, Songkhla 90112

Thailand

*Corresponding author; email: pamornra@yahoo.com

Received: 31 August 2016

Accepted: 17 January 2017 